\title{
Lumen
}

Selected Proceedings from the Canadian Society for Eighteenth-Century Studies

\section{Mapping the Distorted Worlds of Gulliver's Travels}

\section{Nicole E. Didicher}

Volume 16, 1997

Freedom and Boundaries

Émancipation et frontières

URI : https://id.erudit.org/iderudit/1012448ar

DOI : https://doi.org/10.7202/1012448ar

Aller au sommaire du numéro

Éditeur(s)

Canadian Society for Eighteenth-Century Studies / Société canadienne d'étude du dix-huitième siècle

ISSN

1209-3696 (imprimé)

1927-8284 (numérique)

Découvrir la revue

Citer cet article

Didicher, N. E. (1997). Mapping the Distorted Worlds of Gulliver's Travels.

Lumen, 16, 179-196. https://doi.org/10.7202/1012448ar d'utilisation que vous pouvez consulter en ligne.

https://apropos.erudit.org/fr/usagers/politique-dutilisation/ 


\section{Mapping the Distorted Worlds of Gulliver's Travels}

Like most of the travel narratives it imitates in form and style for satiric purposes, Gulliver's Travels comes supplied with maps and other (supposedly) helpful illustrations. Anyone who has read Jonathan Swift's Travels into Several Remote Nations of the World in a good modern edition has seen reproductions of the plates with which early editions of the work were published: a frontispiece, four maps, and the two diagrams in Part III. Most modern editions, unfortunately, do not identify the sources of their reproductions. Even Herbert Davis's 1941 Shakespeare Head Edition (revised 1959), which has twenty full pages listing textual variants, makes no mention of the source of plates other than the frontispieces; in fact, the Davis edition uses reproductions of the 1735 Faulkner version of the maps and diagrams, from vol. III of The Works of J.S.D.D. ${ }^{1}$ This inattention is symptomatic of a general, and unfortunate, lack of concern with what the maps have to tell us about Swift's work.

Three critical pieces dealing with the maps and the internal geography described in Swift's text appeared in the 1940s. Moore, Case, and Bracher all concluded at that time that the plates were probably commissioned by Motte ${ }^{2}$ from a hack engraver, on the basis of a lack of direct evidence that Swift had a hand in their design; these writers also reasoned that the plates cannot have come from Swift because they contain obvious mistakes and are inconsistent with what Gulliver says of the geography of his travels in his narrative. Case's argument was the most insistent of the three: he claimed that there are in fact $n o$ anomalies in Swift's original text - that the contradictions were caused by printers' errors - and he produced his own, more correct, map for the book. Since more recent scholarship finds internal inconsistencies and apparent mistakes essential to a consideration of Swift's work, this sort of reasoning is no longer plausible.

Frederick Bracher's article is more persuasive than Moore's or Case's hypotheses. Bracher discovered that the areas within the Travels plates which correspond to real places are for the most part traced from a map published by Herman Moll entitled 'A New \& Correct MAP of the 
WHOLE WORLD' (1719). When considering an attribution to Swift of the overall design of the Gulliver maps, Bracher is somewhat less dismissive than Moore and Case. He points to the one piece of evidence which shows that Swift may have supplied sketches for the plates - a 1733 letter to Ford in which Swift refers to a proposed reprinting with 'Cutts and all as it was in the genuin copy' (Correspondence 4:211). Bracher also notes some of the indirect evidence of Swift's involvement. He concludes that Swift and his friends might have worked together: 'Ford might have drawn the sketches, or Gay - it is the kind of hoax Gay would have enjoyed' (67). Though Bracher does not note it, in the fall of 1726 , while Swift's text was at the printers, Gay and Pope sent Swift a letter in which they included some pictures and a hand-drawn joke map (Correspondence 3:170, 174). Against the possibility of Swift's involvement, Bracher weighs the fact that

the map-maker clearly had great difficulty in following the contradictory hints as to location given in the text, and produced, in at least one instance, only a desperate compromise. If the map-maker had been one of Swift's companions, he could have asked the author to clear up the geographical anomalies of his text. (67)

Bracher does not appear to consider that Swift might have insisted upon the 'geographical anomalies.'

Recent scholarship either assumes that the Travels map question was settled in the 1940s or shows a sometimes surprising reluctance to deal with the maps. For example, Wagner does a very thorough analysis of the book's 'paratext' - the frontispieces, title pages, tables of contents, and prefatory letters in the various editions of Swift's work - but devotes only two sentences to the remaining plates:

the general undermining of Gulliver's text which Swift orchestrates ... is also true of the maps that precede the four parts of [Gulliver's Travels]. Like the oval portrait of Gulliver that suggests the 'true' reflection of a mirror but really shows an Everyman or nobody, the maps pretend to replicate the world, offering verifiable facts (genuine coast lines known to eighteenth-century readers) and fictional dystopias. (128)

Other recent critics demonstrate an ambivalence about Swift's possible involvement with the design of the maps. Percy Adams, in Travel Literature and the Evolution of the Novel (1984), says both that 'Swift may not have been overly concerned about the maps Motte supplied for that first edition of Gulliver's Travels' and (on the same page!) that 'Swift provided [the] maps' (144). 
One recent study which includes a chapter on Swift's geography, Dirk Passman's 'Full of Improbable Lies': Gulliver's Travels und die Reiseliteratur vor 1726 (1987), follows Case's lead in dismissing the maps as the work of an incompetent hack. Passman even reproduces Case's corrected version for our benefit (246). While he admits that Swift was familiar with a number of Moll's maps and that the Travels maps are based on Moll's, citing Bracher as his source for this information (236), Passman is apparently unwilling to consider Bracher's suggestion that Swift and his friends may have designed them, using a tracing from 'A New \& Correct Map.' Although Passman is concerned with the geography of the Travels as described by Gulliver rather than as it is presented in the maps, his analysis shows the same sort of ambivalence that Adams demonstrates. Gulliver's 'Several Remote Nations of the World,' whether presented in words or engravings, tend to prompt confusion in readers and critics alike. Passman outlines three critical approaches to the geographical anomalies in Swift's text: (a) that Swift was uninformed about geography and prejudiced against its study, and therefore too careless to get his details right; (b) that the original manuscript had no anomalies - the world of the Travels is consistent and reliable, but printers' errors have created problems; and (c) that Swift was aware of Gulliver's mistakes and intended the anomalies as part of his parody of travel literature. While Passman proves the non-validity of the first of these approaches, he seems somehow to support both the second and third, in spite of the inconsistency this creates. For example, he frequently cites Case - virtually the only proponent of the second 'school' - and accepts his arguments in a number of remarks such as 'es ist daher anzunehmen, dass auch dieses Datum ein Transkriptions- oder Druckfehler ist' [we can assume that this information is either a transcription error or a printing error $]^{3}(260)$. At the same time, Passman describes Swift's 'sorgfaltiges Verwirrspiel, das einzig dem Zweck diente, den Leser zu verunsichern' [carefully-worked intentional confusion, which can only serve one purpose: to cause the reader to be uncertain] (247). He also warns that a reader 'kann ... schnell zu Fehlurteilen gelangen, wenn man Swifts Taktik der geographischen Mystifikation unterschatzt' [could easily misjudge the situation if he underestimates Swift's strategy of mystifying the geography] (249).

Although very little attention has been paid to the map plates of the Travels, the two main versions of the frontispiece portrait (1726 London and 1735 Dublin) have recently attracted considerable critical attention as paradoxical sign systems affecting our reading of Gulliver as a character (see especially the excellent work done by Mezciems ['Utopia'], Rodino, and Wagner). I believe the other plates to be as interesting, perplexing, and valuable to our overall understanding of Swift's work 
as the frontispieces are, and that critical discussion of them is long overdue. After all, the process of mapping and the ways that we think when we interpret maps are central to what Swift is saying in the Travels about the unreliability of supposedly reliable facts.

My argument is divided into two parts. First, I outline the evidence which indicates that Swift may have had some part in the design of the maps plates; although this evidence is by no means conclusive, the possibility cannot be ruled out. Second, I offer some preliminary analysis of the map plates, their (mis)use of Moll, and their built-in inconsistencies, along with textual evidence of Gulliver's attitudes to maps and map-makers.

In addition to the two above-mentioned passages in Swift's Correspondence, the evidence for Swift's collaboration on and/or approval of the plates consists of (a) external silent approval, (b) internal distortions in both the real and fictional places in the maps which are similar to the ways Swift uses Gulliver's voyages to distort European realities into fictional societies, and (c) a resemblance between the original frontispiece portrait and Swift's own face. The four maps and two diagrams appear in all the Motte editions of the Travels, along with the first versions of the frontispiece portrait of Gulliver (see Teerink and Scouten 194). Since this first portrait bears a visible resemblance to early portraits of Swift himself (see for example his portrait as a student, reproduced in Rowse 145, we must assume (a) a coincidence, (b) that the engraver was in on Swift's authorship, or (c) that the copytext Swift supplied to Motte through Erasmus Lewis contained sketches for the frontispiece and possibly the other plates, either done by Swift himself or by someone close to him (Mezciems suggests 'an intelligent friend or printer,' 'Utopia' 53). The difficulties in establishing a clear history for the first edition of the Travels are legendary: Swift deliberately obfuscated the process, having the manuscript copied in another hand, and apparently trying to keep his identity a secret from Motte (the classic account is by Harold Williams, Text 4-19). Swift later objected (how seriously we cannot tell) to some of the changes made by Motte and Andrew Tooke, and to the many misprints in the first edition; however, when Swift gave Ford a list of changes to give to Motte for use in the second edition (Teerink and Scouten no. 293), that list made no mention of corrections needed on the plates, and the original plate designs reappear in the corrected edition. In the other available lists of corrections and marked copies which may or may not derive from Swift, there are, apparently, no changes suggested for the plates (see Woolley, Lock, and Treadwell). If Swift had had strong feelings about the imposition of plates he had not requested, we would likely see evidence of this in the suggested corrections. 


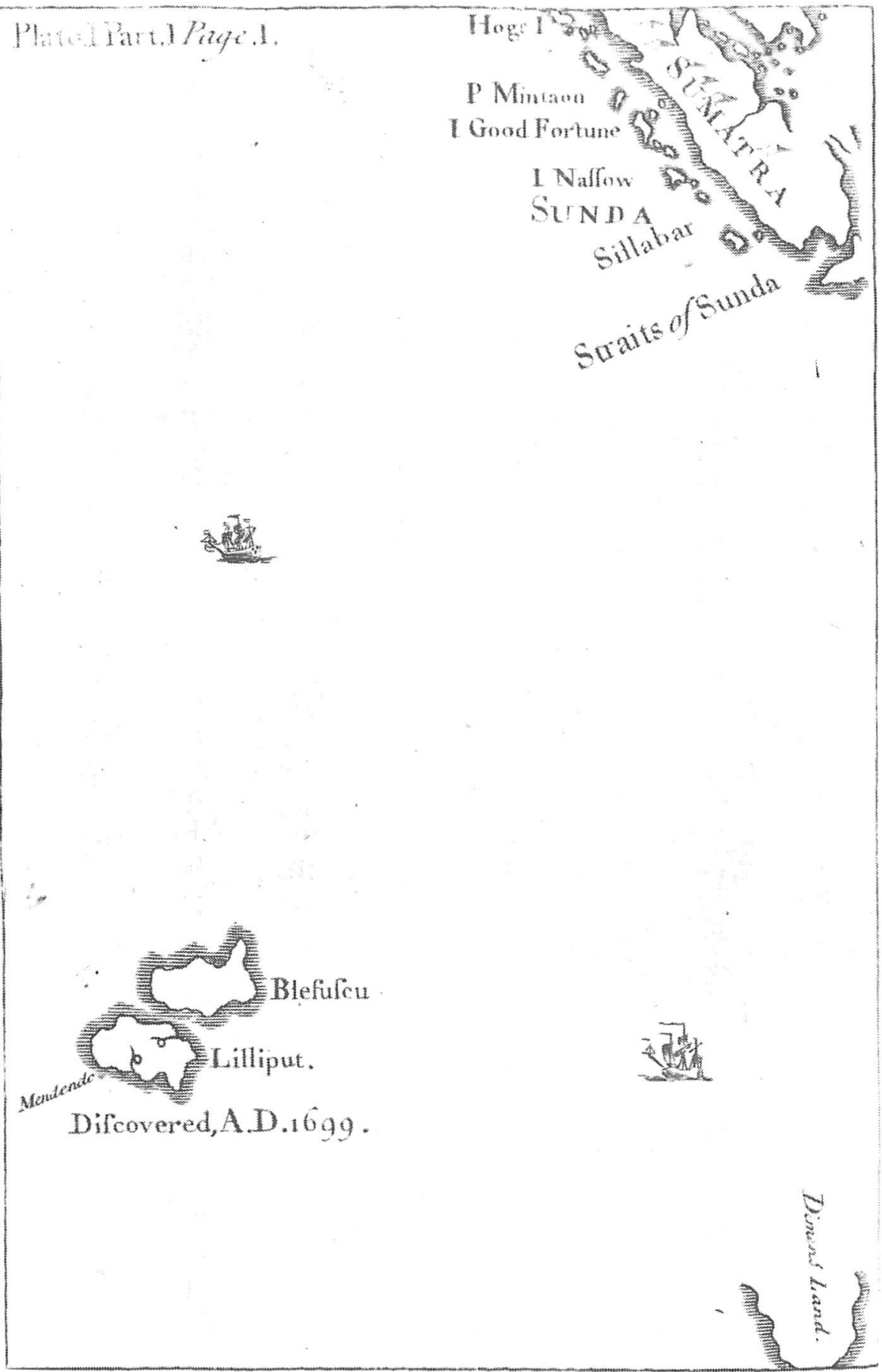

Figure 1: Plate I. Part I. Page 1. 
Most early editions of the Travels, including the translations into Dutch and French (Teerick and Scouten nos. 366 \& 371), contain essentially the same plates as those of the first 1726 large paper 8vo run (re-engraved with very slight variations in spelling, detail, and ornamentation, and, in the case of translations, substitutions for the English words on the maps) ${ }^{4}$; there is no record of Swift's objection. One set of the new copies of the original plates appears in Faulkner's 1735 edition, one which scholars generally agree Swift assisted with and which many editors now use as their copytext. In the Faulkner 1735 works of Swift (produced simultaneously in 8vo large paper, 8vo small paper, and $12 \mathrm{mo}$ ), the frontispiece portrait of Gulliver is updated to imitate the (by that time) famous Jervas portrait of 1710, while the other six plates remain basically the same, implying Swift's satisfaction with them (see Bracher 64-65).

More telling than Swift's lack of objection to the plates, however, is the fact that they contain the sorts of puzzles and paradoxes beloved by Swift and unlikely to be invented by any hack engraver hired by Motte to make the book look more interesting. Relative dimensions are distorted, as in the texts of Parts I and II, and water and land are paradoxically made to occupy the same space. The original plates contain built-in errors, large and small, and other errors have accrued over the years. In the end, the maps are not merely, as A.L. Rowse remarks in his critical biography of Swift, 'designed to give verisimilitude' (142), but form part of what Richard Rodino succinctly calls the 'deliberate autocorruptions' of the text (1057).

Writers of (supposedly) genuine travel narratives in the seventeenth and eighteenth centuries emphasized their own accuracy, but were usually considered notorious liars (see Adams, ch. 3). They also tended to emphasize the newness of their discoveries and the novelty of their works - witness how often the word 'new' appears in titles of travel narratives of this period. Swift uses these characteristics of travel writers to help him demonstrate the impossibility of human accuracy and the folly of thinking oneself modern or original. Gulliver's concern with correctness is undermined by his own inaccuracies and also by those of the maps that accompany his text; Gulliver's clinging to outdated geographical theories shows up Moll's similar clinging and the Travels maps' use of exploded cartographic myths. In Part II, chapter iv, commenting on the size of Brobdingnag, Gulliver writes

I cannot but conclude, that our Geographers of Europe are in a great Error, by supposing nothing but Sea between Japan and California: For it was ever my Opinion, that there must be a Balance of Earth to counterpoise the great Continent of Tartary; and therefore they ought to correct their Maps and Charts, by 


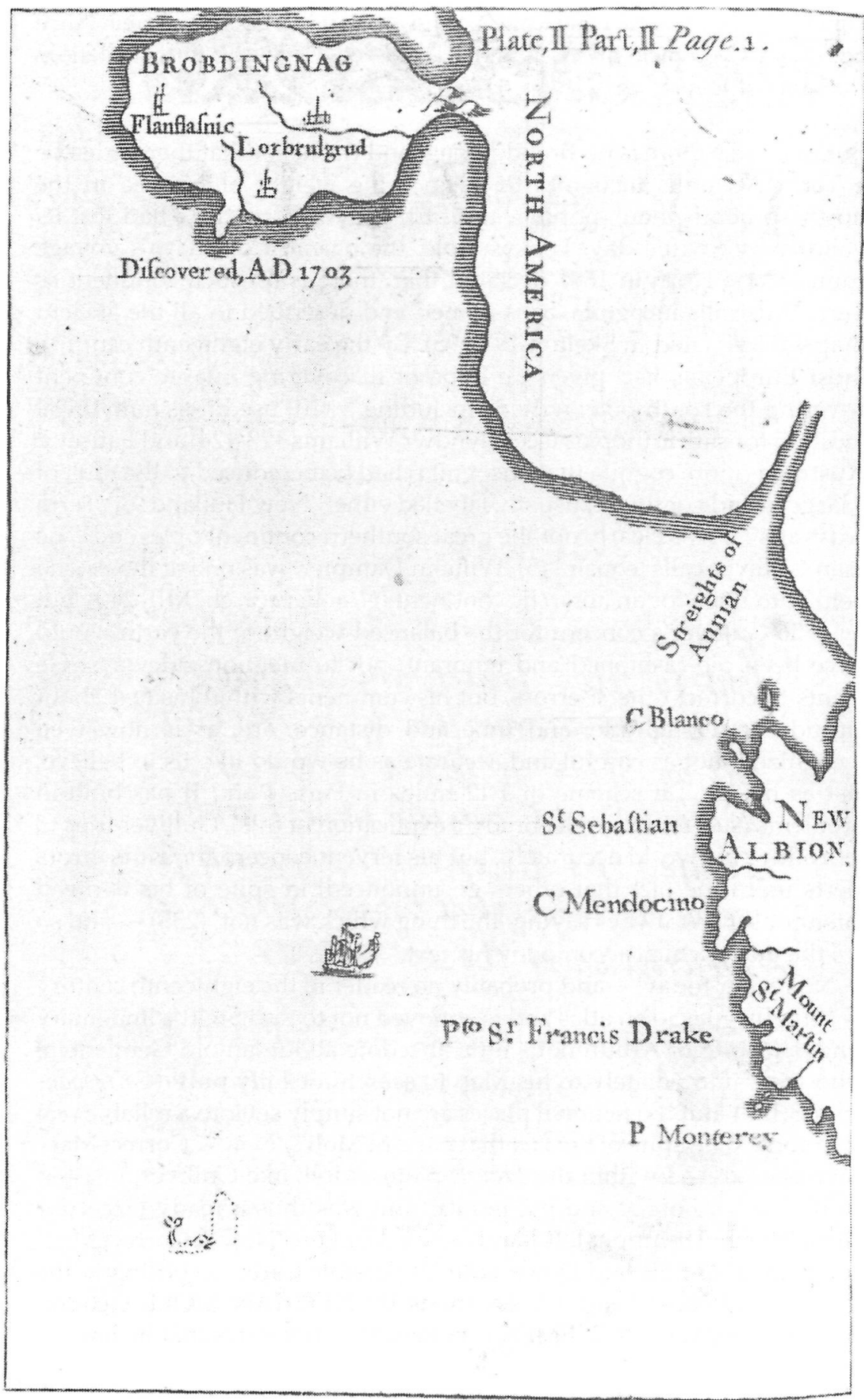

Figure 2: Plate II. Part II. Page 1. 
joining this vast Tract of Land to the North-west Parts of America; wherein I shall be ready to lend them my Assistance. (Travels, ed. Davis 111; further citations from this edition)

But of course there is no Brobdingnag, and the belief that there must be a Terra Australis incognita to balance the weight of Eurasia in the northern hemisphere, popular until the sixteenth century, had lost its validity by Swift's day. For example, the narrator of Sharp's voyage round Cape Horn in 1681 declared that 'there is no such continent as Terra Australis incognita, as is named and described in all the ancient maps' (1684; cited in Skelton 194-195). By the early eighteenth century, most Europeans had given up hope of discovering a large continent covering the south pole; writers, including Swift, used it as a mythical location for satiric utopias (see Glyndwr Williams 123-124, and Fausett). Australia (more cognita than incognita) had been reduced to the rank of a large island continent, usually labelled either 'New Holland' or 'Terra Australis'; it was clearly not the great southern continent of legend. The man Gulliver calls 'cousin' (5), William Dampier, was one of those who held onto hope for an antarctic continent (New Voyage, ch. XIII, 240), but by 1726 Gulliver's concern for the balanced weight of the earth would have been old-fashioned and ignorant, not to mention sideways. He wants to correct others' errors, but his comments within his text about latitude and longitude, and time and distance, are, as is now well recognized, not as careful and accurate as he would like us to believe, just as his careful scheme of 1:12 ratios in Parts I and II has built-in problems (see, for example, Brady's explication of this). Gulliver tries to reproduce his world accurately, but his fervent concern for some errors alerts us to the fact that others go unnoticed; in spite of his avowed intentions, he is always saying 'the thing which was not' (235) - and so are the maps which accompany his text.

No reader today - and probably no reader in the eighteenth century - actually goes to an atlas and is annoyed not to find Swift's imaginary lands, in spite of Arbuthnot's little anecdote about 'an old Gentleman, who went immediately to his Map to search for Lilly putt' (Correspondence 3:180). But the fictional places are not simply set into a reliable real map context, in spite of the fact that parts of Moll's 'New \& Correct Map' have been traced within the Travels plates. Moll, like Gulliver, insisted on his own accuracy and modernity, and was thus a ready target for satiric attack. The upper left-hand cartouche of the 'New \& Correct Map' proclaims that 'it is laid Down with all possible Care, According to the Newest and Most Exact Observations By HERMAN MOLL Geographer.' In the 'ADVERTISEMENT' below, Moll reiterates that he has 


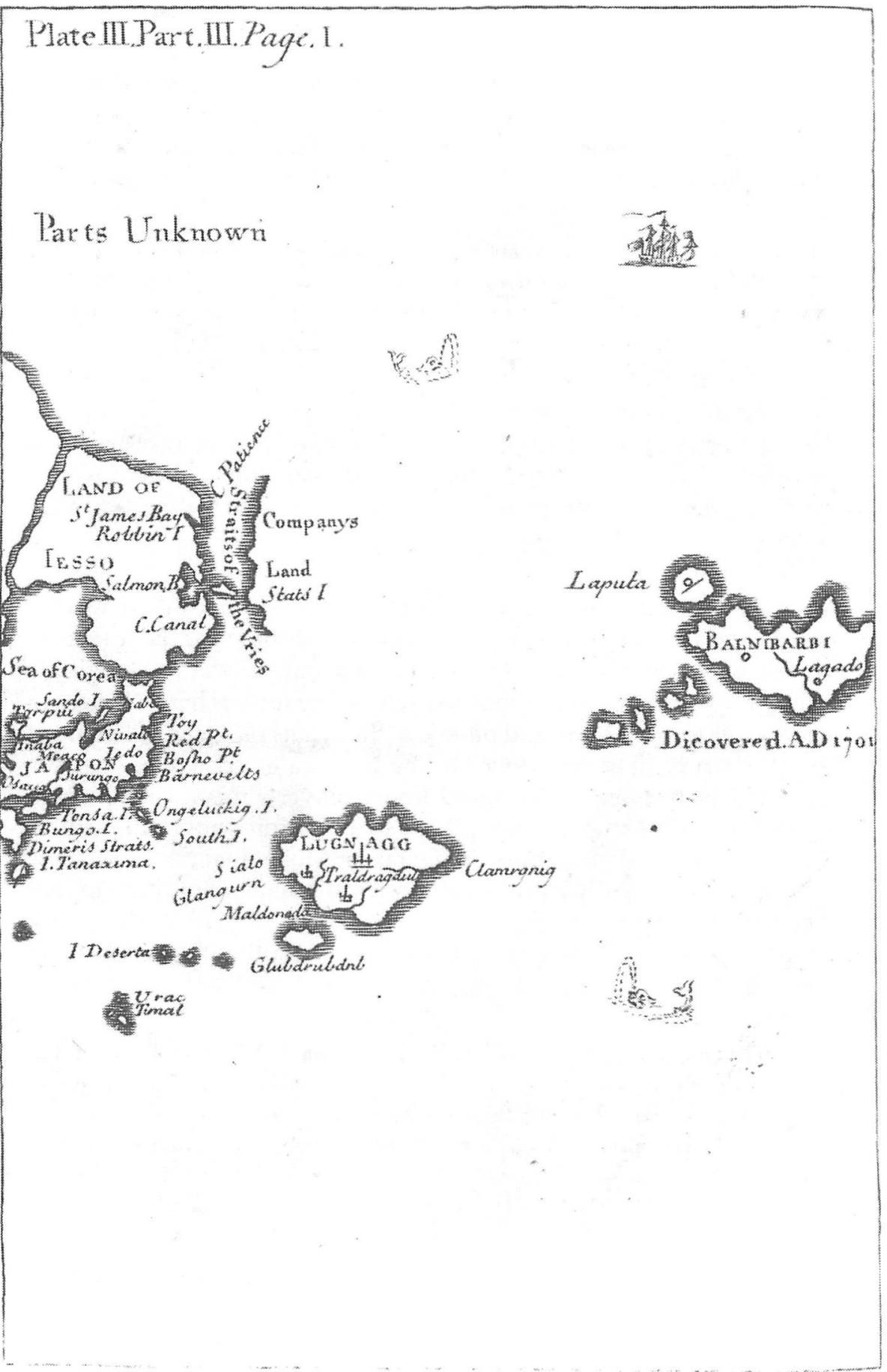

Figure 3: Plate III. Part III. Page 1. 
omitted no Pains to have them [this series of maps] very correctly done, according to the Newest Observations and Latest Discoveries ... I hope Noblemen, Gentlemen and others, will not suffer themselves to be imposed upon by Old, incorrect, and falsly projected Maps, under what denomination soever they may be represented to the Publick, without taking a little Care to look into and examine them.

But Moll's map does in fact contain out-dated information merely copied from 'old' and 'incorrect' maps, and we need to take a little care to look into it. Moll's empty posturing makes him a natural target; in Part IV, chapter xi, Swift has Gulliver take Moll ironically to task:

This confirmed me in the Opinion I have long entertained, that the Maps and Charts place this Country [New Holland] at least three Degrees more to the East than it really is; which Thought I communicated many Years ago to my worthy friend Mr. Herman Moll, and gave him my Reasons for it, although he hath rather chosen to follow other Authors. (284)

We as readers must distrust anyone whom Gulliver can call 'my worthy friend,' and Gulliver's fussing over a mistake of three degrees in an era when it was extremely difficult to get an accurate reading of longitude points us to other, graver, errors on Moll's part, such as his inclusion, in the 'New \& Correct Map' and others, of the Straits of Anian, when most Europeans no longer thought such a body of water existed (see below). The parts of the Moll map traced into Gulliver's maps contain such errors, but the tracings are also placed so as to omit important features (Australia, for example), thus exaggerating Moll's inaccuracies. These maps are as little trustworthy as all the scientific details Gulliver supplies to convince us of his veracity.

Isaac Asimov (sounding almost as naive as Arbuthnot's rhetorical old gentleman) says this of the map to Part I (see figure 1$):^{5}$

Had Gulliver actually been driven to the northwest of Van Diemen's Land to that latitude, he would have found himself at least a hundred miles inland on the continent of Australia. But then, the southern shores of Australia had not been discovered in Gulliver's time, or at the time the book was published, either. The coasts of that island continent were not well mapped until the voyage of Captain Cook in 1770. (7)

In fact, Swift's audience in 1726 would have realized that New Holland was north and west of Van Diemen's Land (which we now call Tasmania), even though the Dutch had not completely mapped the shoreline. In fact, many people assumed that the continent was somewhat larger 


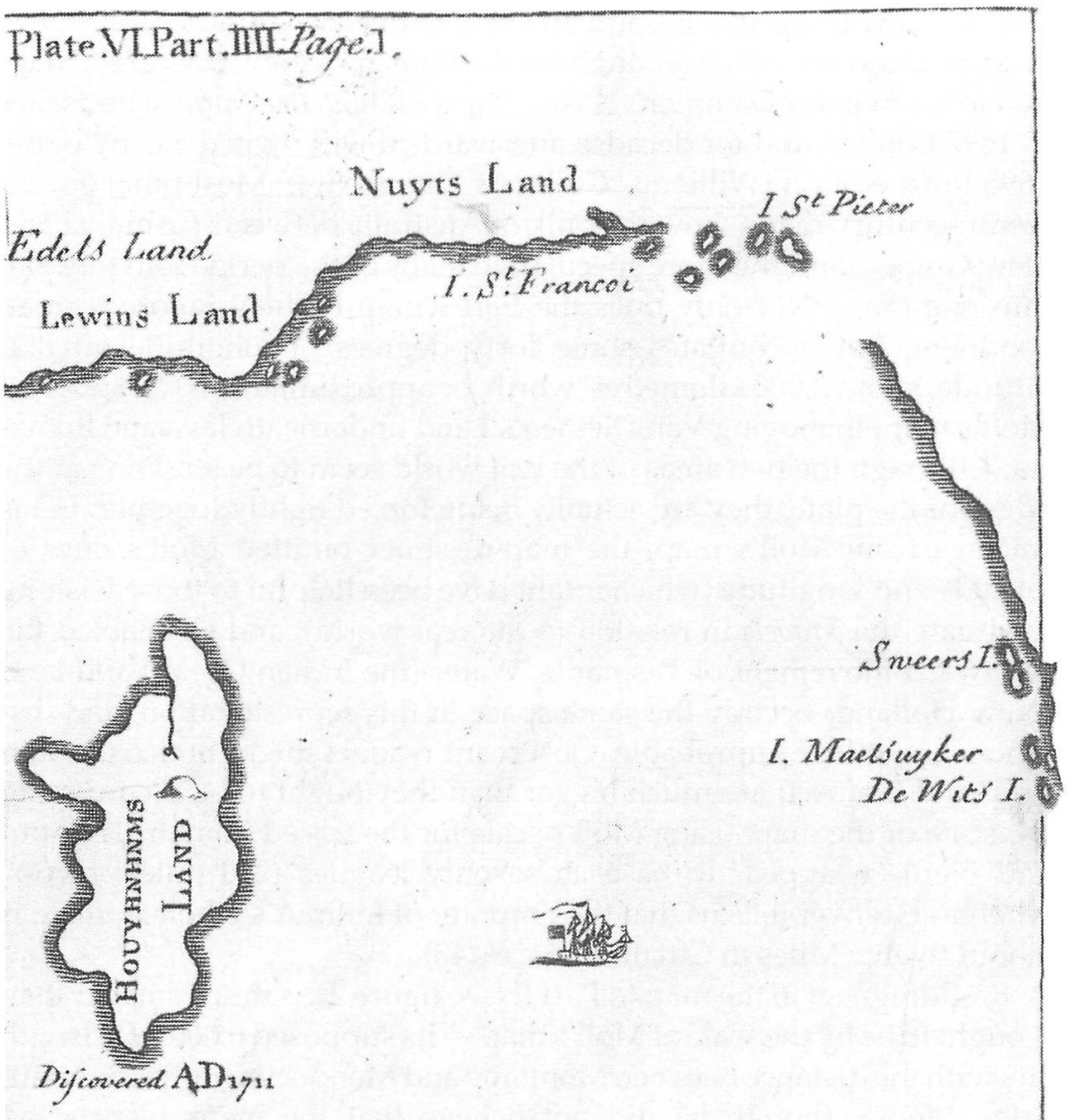

Tis

Figure 4: PlateVI. Part IV. Page 1. 
than we now know it to be, and attached onto New Guinea. Moll shows New Holland accurately enough for the time in 'A New \& Correct Map' and in his map for Dampier's A New Voyage Round the World, a bestseller in 1697 London and for decades afterwards (Swift owned a copy of the 1698 third edition [Williams, Gulliver's Travels xiv]). Most other seventeenth-century maps show the bulk of Australia between Tasmania and New Guinea, and the more speculative maps of the period join these all into one mass. Not only does the Part I map blithely ignore a small continent, but it conflates some forty degrees of longitude (at that latitude, about 3,000 kilometres' worth, or approximately 500 leagues by Moll's map) in moving Van Diemen's Land underneath Java and Sumatra. Although the two areas of the real world seem to be straining at the edges of the plate, they are actually being forced tightly together. In his tracings from Moll's map, the map-designer omitted Moll's lines of latitude and longitude (which might have been helpful to those wishing to situate the Travels in relation to the real world), and so enabled the westward movement of Tasmania. Water (the Indian Ocean) and land (New Holland) occupy the same space in this representation, and distances are wildly improbable. Observant readers might notice that Lilliput and Blefuscu are much bigger than they ought to be according to the scale of the map; using Moll's scale for the traced Sumatra, Lilliput and Blefuscu appear to be each seventy leagues ( 210 miles) across, whereas Gulliver tells us that the Emporer of Lilliput's whole domain is 'about twelve Miles in Circumference' (43).

Brobdingnag, in the map to Part II (see figure 2), is much smaller than it ought to be by the scale of Moll's map - its supposed 6,000 mile length jars with the distance between Monterey and Mendocino rather dramatically. Moore, though he did not believe that the maps were at all humorous, pointed out one of the humorous effects of this:

The peninsula appears, not as a magnificent counterpoise to Tartary ... but as a wen-like projection from the North American coast. Any map of Brobdingnag required, like Demosthenes' requirement for an orator, Boldness; and this mapmaker was not bold. Quite as bad, he had not read the story carefully. (225)

Moore does not seem to consider that the mistake in the map might be purposeful, distorting the projection of Brobdingnag in the opposite direction from the previous distortion of Lilliput (small becomes bigger; big becomes smaller). Also, the map to Part II owes as much to cartographic myth as it does to Moll. The position and shape of Brobdingnag, as given in Swift's text, may have been inspired by another long-discounted geographical theory: a peninsula labelled 'Quivira' by the Spanish in the sixteenth century (see sixteenth-century world maps such as 
those by Ortelius or Mercator). And the Straits of Anian, a supposed passageway between North America and Asia, placed by Moll at the upper extremity of his North America, had been long discounted as myth (interest in a northwest passage was revived later, in the 1740s and '50s). Even Drake's chaplain-chronicler, after they explored north from California at the end of the sixteenth century, expressed doubts of its existence:

we coniecture, that either there is no passage at all through these Northerne coasts (which is most likely), or if there be, that yet it is vnnauigable. Adde hereunto, that though we searched the coast [of North America] diligently, euen vnto the 48 deg., yet found we not the land to trend so much as one point in any place towards the East, but rather running on continually North-west, as if it went directly to meet with Asia. (52)

Sixteenth-century maps show the Strait where it was supposed to be, in approximately the position we place the Bering Strait on our maps (Bering made his discovery in 1728 , two years after the initial publication of the Travels). The Travels plate, however, extends the coast-line of North America northwards beyond Anian, so that the strait appears in the centre; instead of being at the edge of known space and nearly hidden by a compass inset, as it is on Moll's map, the traced Anian is centrally emphasized and, in a nice correspondence with Gulliver's bodily concerns in the Travels, rather anal-looking.

Part III concentrates on the area on the other side of the Pacific Ocean, a third region of the earth which still contained uncharted waters in which Swift could put his 'Remote Nations.' Narratives by the Jesuit missionaries to the islands of Japan were in great demand with European readers in the sixteenth and seventeenth centuries (see Adams 55-56), and the waters southeast of Japan were a fruitful area for the placement of imaginary lands, since islands seemed to appear and disappear there regularly. (Some of these mysteries were caused by inadequate navigation technology, but sometimes islands have actually appeared or disappeared; see Stommel.) No traveller to the East Indies was surprised to discover new islands in the Western Pacific: for example, Dampier recounts the finding and naming of five new, 'very thick inhabited' islands south of Formosa $(288,285)$. The map to Part III (see figure 3 ) is the only one without direct tracings from Moll, though it is based loosely on his map. Since we know that Part III was the last of the four parts to be written (Correspondence 3:5), it may be that the other three maps were designed on one occasion, using Moll's 'New \& Correct Map,' and the designer (whether Swift or a friend) sketched out the plate for Part III at a later date, when he no longer had direct access to the Moll map. Both 
the Travels map and Moll's are based on maps from the explorations of a Dutch explorer named Maarten de Vries, who was trying to find North America from the Asian side in 1643. He did not find the entry to the northwest passage, but he believed he had, so that the area marked 'Company's Land' in de Vries's map, Moll's, and Gulliver's is supposed to be the west edge of North America (see Skelton 171-174). As in the map to Part I, the waters and fictional islands in Gulliver's map are overlapped with putative land, at the same time in the Pacific Ocean and paradoxically in the middle of North America (Company's Land projected eastward). This arrangement precludes the possibility of Brobdingnag, which by Gulliver's description is large enough to fill the Pacific (in fact, to overfill it, since early eighteenth-century geographers underestimated the size of that ocean). Case was particularly affronted by the map to Part III; as part of his attempt to eliminate all inconsistencies from the Travels, he had to make drastic changes to this map, including the production of an elongated and unlikely Balnibarbi nearly as big as Australia. But Case encountered difficulties with both the geography and chronology of Part III (see 58-60, 65-67) because it is in fact full of extraordinary contradictions, and so is the map which accompanies it (though they are mostly different contradictions: for example, Maldonada has been moved from Balnibarbi to Luggnagg in the face of direct textual evidence).

The Map to Part III also demonstrates one of the inherent limitations of two-dimensional maps: how can a flat representation of a three-dimensional world possibly represent a flying island? In both the map to III and the diagram of Laputa's movements, Laputa is made to appear, not as superimposed above the larger landmass (as it ought to be from the vertical point of view of the map), but north of Balnibarbi's northern coast-line.

In Part IV (see figure 4), we return to the region of Australia. Moll's and other eighteenth-century maps of this area are based on Dutch maps of the southern coast of Australia/New Holland (using the discoveries of Dirk Hartog in 1616 and Fredrik Houtman in 1619; see Schilder). In the Travels map, the coast-line north of Houyhnhnmland is the south edge of New Holland, traced from Moll; this is one of the coast-lines omitted from the Part I map in order to eliminate Australia. To its east is a slightly different tracing of Tasmania from that used in the map to Part I: the islands are omitted in I, while in IV a long fictional coast-line going north into unexplored territory is added (though it does not join onto the other coast by I. St. Pieter, thus stopping short of defining and stabilizing the Australian coast-line). The New Holland missing from the map in Part I is seen, at least partially, in IV; however, the section which appears in both, Van Diemen's Land, is deliberately altered in each case 
from Moll's version. Surely a hack engraver, if he were simply tracing the bits of Moll which seemed most appropriate, would not bother to remove the islands in the first version and to add an extension of coast-line in the second, so that they should not give a stable reference point.

Incidentally, Houyhnhnmland, since it lacks the urban centres marked on the other fictional lands in the plates, features at its centre the only landmark associated with humanity in Part IV: the mountain to which the two original Yahoos retreated when they made landfall on the island. Thus, visually, the map for Part IV draws our attention more to Yahoos than to Houyhnhnms, and reminds us of the excesses and corruptions to which all human societies are susceptible.

The four maps with which the Travels is provided give visible consideration to the geographic and topographic impossibilities of the fictional lands Gulliver describes, and they create their own impossibilities, with I contradicting IV and II contradicting III. Altogether, it seems safe to say that the maps are not intended to give verisimilitude, but rather, while seeming to be trustworthy and stable, they are meant to undermine our ideas of what the world is like through puzzle and paradox. Like the many prefaces to Tale of $a$ Tub, or the prefatory letters to the Travels, the maps enfold the text and eat away at it corrosively, contributing to its self-destructive nature.

David Fausett, though not referring to Swift's work, points out that 'Utopias and imaginary voyages spoke about the world and the way culture mediates one's experience of it and showed by implication how objectivity was being precipitated out of the multiple subjectivities of societies . . . what is fact in one place is fiction in another, and an awareness of this truth destabilizes all truth' (173-174). The (fictional) traveller with a tale to tell proclaimed it to be a truthful eye-witness account, but he or she told of things remote and marvellous; moreover, travel writers were notorious as liars - the more insistent the narrator's claim to honesty, the less he or she was to be trusted (see Adams, ch. 3). This ambivalence in travel literature in general, since it simultaneously displays its trustworthiness and tries to deny its obvious untrustworthiness, bears an analogical relationship with maps as alternate semiotic systems for communicating truth about remote areas of the world. Maps present and insist on their truthfulness, usefulness, and verifiability; i.e., they claim to re-present part of the real world and imply that if we have a map we can reach the location delineated and recognize the landscape there. However, at the same time, the sign system that is a map depends on our assumptions of its untruthfulness: it represents rather than presents; it reduces three dimensions to two; it gives us an illusory and 
god-like vertical view of the land which it was impossible (until recently) to duplicate in reality. ${ }^{6}$ Like travel literature, maps are attractive illusions of truth, always potentially false. In Swift's Travels in particular, as opposed to the general relationship between maps and travel literature, the maps are also in an analogical relationship with Gulliver's story. Gulliver insists on his trustworthiness and is untrustworthy; he proclaims his honesty in the final chapter by quoting a notorious liar (IV, xii 292); he is 'Splendide Mendax' (1735 frontispiece), the splendid liar who all his neighbours agree can never lie. The Travels maps are in part traced from a source which also over-proclaims its own veracity, just as travel narratives and Gulliver do. The invented sections of the maps, the representations of the fictional lands Gulliver discovers, contradict each other and what Gulliver says of the geography in his text, and they are further destabilized by being set within the already compromised context of Moll's maps and the naive assumptions of map-makers and map-readers. Just as Swift uses the contradictions between Gulliver's claim of truth and his actual deceptions to undeceive us about the stability of human knowledge and capacity, so the maps in the Travels use our assumptions about the verisimilitude of maps and the actual contradictions within the maps themselves to undeceive us about our ultimately limited human subjectivity. Like the written text, and the many written texts within the written text, the plates are markers of stability and knowledge which in the end point out that all stability and knowledge are problematic.

\section{NICOLE E. DIDICHER}

University of Minnesota Morris

\section{Notes}

1 Teerink \& Scouten nos. 41, 8 vo and 49, 12mo; the Faulkner 18 mo edition has slightly different plates; see Teerink and Scouten 25.

2 Benjamin Motte published the original 1726 edition of the Travels. The Motte issues which Teerick and Scouten list as A, AA, and B (nos. 289-291) appeared in Oct., Nov., and Dec. of 1726 respectively; they have the same maps and diagrams, but two different states of the frontispiece.

3 My thanks to Susan Tweney for assistance with the German translations.

4 As an example of variants caused by re-engraving, see Motte's 3rd ed. $12 \mathrm{mo}$ of 1727 (T\&S no. 294), in which the maps are narrowed and small changes introduced: e.g., the 'Straits of Sunda' in Map I become the 'Straits of Sunday.' These $12 \mathrm{mo}$ plates were also used by Bathurst in his $17518 \mathrm{vo}$ ed. (T\&S no. 69). A 
complete catalogue of the variations would tell us something about when and how often the plates were re-engraved, but is beyond the scope of this paper.

5 These are reproductions of the original 1726 states of the maps. Figures 1, 3, and 4 have been photographed from an AA copy, and figure 2 from a copy of the B issue. These copies are from the William Ready Division of Archives and Research Collections at McMaster University, and images are reproduced with permission of the McMaster University Library.

6 For further discussion of the psychological and semiotic implications of maps, see Gregory, Wood, and Robinson and Petchenik.

\section{Works Cited}

Adams, Percy G. Travel Literature and the Evolution of the Novel. Lexington: U of Kentucky P, 1983.

Asimov, Isaac. Introduction and Notes. The Annotated Gulliver's Travels. New York: Potter, 1980.

Bracher, Frederick. 'The Maps in Gulliver's Travels.' Huntington Library Quarterly 8 (1944): 59-74.

Brady, Frank. 'Vexations and Diversions: Three Problems in Gulliver's Travels.' Modern Philology 75 (1978): 346-367.

Case, Arthur. Four Essays on 'Gulliver's Travels'. Princeton: Princeton UP, 1945.

Dampier, William. A New Voyage Round the World. 1697. New York: Dover, 1968.

Drake, Sir Francis. 'The World Encompassed by Sir Francis Drake.' The World Encompassed and Analogous Contemporary Documents. Intro: Sir Richard Carnac Temple. New York: Cooper Square, 1926. Rpt. 1969.

Fausett, David. Writing the New World: Imaginary Voyages and Utopias of the Great Southern Land. Syracuse, NY: Syracuse UP, 1993.

Gregory, Derek. Geographical Imaginations. Cambridge, Massachusetts \& Oxford: Blackwell, 1994.

Lock, F.P. 'The Text of Gulliver's Travels.' Modern Language Review 76 (1981): 513-533.

Mezciems, Jenny. "'Tis not to divert the Reader': Moral and Literary Determinants in some Early Travel Narratives.' Prose Studies 5:1 (1982): 1-19.

. 'Utopia and 'the Thing which is not': More, Swift, and Other Lying Idealists.' University of Toronto Quarterly 52 (1982): 40-62.

Moll, Herman. 'A New \& Correct MAP of the WHOLE WORLD ....' 1719; tipped into The World Describ'd; or, a new and correct sett of maps... London: Bowles, Moll, [1709-1736]. [The copy I viewed is held by the Royal Ontario Museum, Toronto, in its Canadiana Collection.]

Moore, John Robert. 'The Geography of Gulliver's Travels.' JEGP 40 (1941): 214-228. 
Passman, Dirk. 'Full of Improbable Lies': Gulliver's Travels und die Reiseliteratur vor 1726. Aspekte der englischen Geistes- und Kulturgeschichte 10. Frankfurt am Main: Peter Lang, 1987.

Robinson, Arthur H. \& Barbara Bartz Petchenik. The Nature of Maps: Essays toward Understanding Maps and Mapping. Chicago \& London: U of Chicago P, 1976.

Rodino, Richard. "Splendide Mendax': Authors, Characters, and Readers in Gulliver's Travels.' PMLA 106 (1991): 1054-1070.

Rowse, A.L. Jonathan Swift: Major Prophet. London: Thames \& Hudson, 1975.

Schilder, G. 'New Cartographical Contributions to the Coastal Exploration of Australia in the Course of the Seventeenth Century.' Imago Mundi 26 (1972): 41-44.

Sherbo, Arthur. 'Swift and Travel Literature.' Modern Language Studies 9 (1979): 114-127.

Skelton, R.A. Explorers' Maps: Chapters in the Cartographic Record of Geographical Discovery. London: Routledge \& Kegan Paul, 1958.

Stommel, Henry. Lost Islands: The Story of Islands That Have Vanished from Nautical Charts. Vancouver: U of British Columbia P, 1984.

Swift, Jonathan. Correspondence of Jonathan Swift. 5 vols. Ed. Harold Williams. Oxford: Clarendon, 1963.

. Gulliver's Travels. Ed. Herbert Davis. Intro. Harold Williams. The Prose Writings of Jonathan Swift. Vol.11. Oxford: Basil Blackwell, 1941; rev. ed. 1959.

Teerink, H., and Arthur H. Scouten. A Bibliography of the Writings of Jonathan Swift. 2nd ed, revised. Philadelphia: U of Pennsylvania P, 1963.

Treadwell, Michael. 'The Text of Gulliver's Travels, Again.' Swift Studies 10 (1995): 62-79.

Wagner, Peter. 'Swift's Great Palimpsest: Intertextuality and Travel Literature in Gulliver's Travels.' Dispositio 17 (1992): 107-132.

Williams, Glyndwr. 'Buccaneers, Castaways, and Satirists: The South Seas in the English Consciousness Before 1750.' Eighteenth-Century Life 18 (1994): 119-128.

Williams, Harold. 'Introduction.' Gulliver's Travels. Ed. Herbert Davis. The Prose Writings of Jonathan Swift. Vol. 11. Oxford: Basil Blackwell, 1941; rev. ed. 1959. ix-xxviii. . The Text of Gulliver's Travels. Cambridge: Cambridge UP, 1952.

Wood, Denis. The Power of Maps. New York \& London: Guilford, 1992.

Woolley, David. 'The Stemma of Gulliver's Travels: a First Note.' Swift Studies 1 (1986): 5154.

.'Swift's Copy of Gulliver's Travels: The Armagh Gulliver, Hyde's Edition, and Swift's Earliest Corrections.' The Art of Jonathan Swift. Ed. Clive T. Probyn. London: Vision, 1978. 131-178. 